\title{
Inklusi Keuangan Perbankan Syariah Berbasis Digital-Banking: Optimalisasi dan Tantangan
}

\author{
Abdus Salam Dz. \\ Guru Besar Ilmu Manajemen IAIN Syekh Nurjati Cirebon \\ Email: abdussalamdz@syekhnurjati.ac.id
}

\begin{abstract}
Abstrak
Kehadiran dan praktik bank syari'ah di Indonesia hampir tiga dekade, tetapi perkembangan bisnisnya tidak sebanding dengan waktu yang telah dilaluinya. Pada akhir tahun 2016, perkembangan bank syariah mencapai 19,67 persen, dengan pangsa pasar 5,12 persen. Pencapaian ini jelas tidak seimbang dengan potensi negara ini. Beberapa penyebabnya adalah produk dan jasa syariah yang diterima oleh nasabah, jarak ke lokasi bank terdekat, biaya yang tinggi untuk transaksi dengan volume kecil, informasi yang terbatas, tingkat pengetahuan syariah yang rendah, pendapatan yang rendah, dan antrian yang panjang ketika bertransaksi secara langsung. Ini adalah bukti dari rendahnya tingkat literasi dan inklusi keuangan syariah, masing-masing 8,11 persen dan 11,06 persen. Penting untuk mengoptimalkan inovasi untuk menyelesaikan kesenjangan layanan dengan menempatkan teknologi informasi dan komunikasi melalui digitalisasi layanan sehingga hubungan antar bank dengan masyarakat menjadi lebih dekat, hemat, efisien, cepat, dan murah.
\end{abstract}

Kata Kunci: Inklusi Keuangan, Perbankan Syariah, Digital Banking

\begin{abstract}
The presence and practice of sharia banks in Indonesia has been almost three decades, but the development of its business is still not comparable with the time that has been passed. By the end of 2016, the growth of sharia banking has reached 19.67 percent, with the market share of sharia banking at 5.12 percent. This achievement is clearly not comparable with the potential of this nation. Some of the causes are Sharia products and services are perceived by the people, the distance to the nearest bank office location, the high cost for small volume transactions, limited information, low level of sharia knowledge, the low-income, plus the long queue when the transaction is direct. This is evident from the low level of literacy and inclusion of Islamic finance, each of only 8.11 percent and 11.06 percent. It is necessary to optimize innovation to solve the service gap by placing information and communication technology through service digitization so that the inter-bank relationship with the community becomes closer, thrifty, efficient, quick and cheap.
\end{abstract}

Keywords: Financial Inclusion, Sharia Banking, Digital Banking 


\section{Pendahuluan}

Bank adalah jantung perekonomian negara, tanpa perbankan kegiatan ekonomi menjadi lumpuh. Ketika dunia perbankan maju pesat berdampak pada pertumbuhan ekonomi nasional maupun global. Perbankan merupakan pusat transaksi ekonomi. Dalam perbankan ritel ditentukan oleh penyerapan dana pihak ketiga dan ekspansi usaha perbankan ditentukan oleh pembiayaan. Lembaga bank memediasi masyarakat yang surplus unit dilendingkan kepada yang defisit unit.

Perkembangan teknologi informasi membawa banyak perubahan dan pergeseran. Kesuksesan bisnis saat ini lebih banyak dipengaruhi oleh seberapa cepat perusahaan dapat merespons perubahan tersebut. Transformasi mendesak dunia perbankan adalah digitalisasi layanan. Digitalisasi tidak hanya sekedar bertujuan untuk memindahkan transaksi manual menjadi otomatis. Digitalisasi perbankan memiliki arti yang lebih luas terutama untuk memenuhi kebutuhan konsep bisnis perbankan, menyediakan layanan terkini guna menguatkan customer transaction behavior. Bermunculannya perusahaanperusahaan keuangan berbasis teknologi atau financial technology (fintech) memaksa industri perbankan syariah harus berbenah. Fintech memiliki teknologi dan inovasi untuk menjangkau nasabah yang tidak dapat mengakses sistem perbankan tradisional.

Di tengah pesatnya penggunaan teknologi oleh masyarakat umum, industri perbankan mau tak mau harus mengikuti tren tersebut. Layanan online dan mobile banking menjadi suatu hal yang niscaya ada di perbankan. Perusahaan multinasional Accenture menganalisa bahwa 25 bank ritel besar di Amerika Serikat mengeluarkan dana lebih dari 50 miliar dolar AS setahun guna mengoperasikan lebih dari 43 ribu kantor cabang di seluruh negara tersebut.
Rata-rata pembukaan kantor cabang baru pun berbiaya tidak kurang dari US\$ 2 juta.

Digital banking, inovasi awal memahami gap layanan dan potensi pemanfaatan teknologi yang demikian besar, perbankan pun melahirkan mobile dan internet banking yang terbukti efektif dalam memperluas jangkauan layanan, menyiasati tantangan geografis. Inovasi tersebut juga berhasil menciptakan efisiensi serta membuka opsi terhadap lebih banyak pilihan produk dan layanan perbankan, seiring dengan digemarinya masyarakat cara-cara pemasaran online. Digitalisasi yang pesat membuat dunia perbankan mengubah strategi bisnisnya dengan menempatkan teknologi sebagai unsur utama dalam proses inovasi produk dan jasanya. Dengan adanya jaringan teknologi informasi yang makin canggih ini, maka hubungan antar bank dengan nasabahnya menjadi lebih dekat, hemat, efisien, cepat dan murah.

Digitalisasi adalah perjalanan yang sulit dan rumit. Menangkap peluang yang disediakan akan membutuhkan investasi, perencanaan yang cermat serta pengambilan keputusan terkoordinasi yang mencakup seluruh bank. Perusahaan yang gagal untuk memahami resiko merusak waralaba ini yang dibangun dari generasi ke generasi (Khanna, 2016). Tetapi jika CEO berhasil mengatasi berbagai tantangan strategis yang ditimbulkan oleh kemajuan digital, mereka dapat memposisikan bisnisnya untuk bersaing secara efektif dan menangkap lintasan pertumbuhan jangka panjang.

World Economic Forum (2015) memprediksi Indonesia akan menjadi salah satu pasar digital terbesar di Asia Tenggara pada tahun 2020. Hal ini mempertegas peluang inklusi keuangan digital, diperkuat dengan kenyataan baru sekitar 36 persen orang dewasa di Indonesia yang memiliki rekening di bank atau sekitar 120 juta orang masuk dalam kategori unbanked. Kontradiksinya, Asosiasi Penyelenggara 
Jasa Internet Indonesia (APJII) mencatat 132,7 juta orang Indonesia telah terhubung ke internet, berkat perkembangan infrastruktur dan mudahnya mendapatkan smartphone atau perangkat genggam. Angka ini naik pesat dari tahun 2014 yang hanya mencapai 88 juta orang. Industri perbankan melihat gap ini, bergerak maju dan berkolaborasi untuk meningkatkan sistem, strategi dan fungsi, agar masyarakat dapat membuktikan bahwa transaksi dengan bantuan teknologi itu mudah dan cepat (kompas.com).

Indonesia, salah satu negara berkembang dengan peningkatan industri digital yang sangat pesat dalam beberapa tahun terakhir ini, termasuk tren penggunaan perangkat digital. Otoritas Jasa Keuangan (OJK) selaku regulator industri jasa keuangan di Indonesia mengumumkan bahwa jumlah nasabah pengguna $e$-banking (SMS banking, phonebanking, mobile banking dan internet banking) meningkat sebesar $270 \%$ dari 13,6 juta nasabah di tahun 2012 menjadi 50,4 juta nasabah pada tahun 2016. Sementara frekuensi transaksi pengguna $e$-banking meningkat $169 \%$ dari 150,8 juta transaksi tahun 2012 menjadi 405 juta transaksi pada tahun 2016. Data tersebut menunjukkan bahwa tren perubahan menuju era digital banking sedang terjadi di Indonesia. Kepemilikan perangkat digital seperti smartpone (43\%), Laptop dan komputer (15\%), tablet (4\%) streaming TV (1\%), e-reader (1\%), hingga wearable (1 \%). Pasar e-commerce mengalami pertumbuhan 20,7 \% dengan total pedapatan US\$ 5,6 miliar pada 2016, dengan tingkat belanja online 13,4 \% dan perkiraan akan meningkat ke angka 21,2 pada 2021.

Jika selama ini digitalisasi layanan keuangan perbankan menggunakan SMS banking, Internet banking, Mobile banking, Brachless banking dalam upaya mendukung inklusi keuangan, tidak lama lagi akan diluncurkan fintech lending untuk Bank
Umum (Commercial Banks) dengan menerapkan Digital Branch (Press rilis OJK, 17-01-2017). Digital Branch adalah kantor cabang bank yang full digital. Nasabah dapat melakukan transaksi keuangan secara mandiri pada setiap Digital Branch. Pertumbuhannya yang pesat terlihat dari nilai investasi yang ditanamkan modal ventura (VC) ke startup fintech. Tak kurang US\$ 13,8 miliar sepanjang 2015, lebih dari dua kali penanaman modal selama 2014. Saat ini ada 19 fintech yang bernilai di atas US\$ 1 miliar atau kerap disebut "unicorn". Fintech mempunyai sejumlah kelebihan dibandingkan bank tradisional. Fintech lebih efisien karena mampu menekan biaya operasional, sehingga bisa memberikan fasilitas pinjaman/pembiayaan yang lebih murah. Selain itu, fintech mampu melayani lebih personal dan menjangkau masyarakat di wilayah pelosok, yang sulit dijangkau perbankan.

Perkembangan digital banks di atas merupakan gambaran kondisi digitalisasi keseluruhan dunia perbankan secara nasional dan internasional, lalu bagaimana dengan perbankan syariah, khususnya di Indonesia? terutama dalam meratifikasi program inklusi dan literasi keuangan dalam upaya merespons untuk ekspansi layanan perbankan berbasis bagi hasil ini.

\section{Pembahasan \\ Landasan Teori}

Bank syariah adalah bank yang menjalankan kegiatan usahanya berdasarkan prinsip syariah. Bank syariah berperan sebagai lembaga perantara (intermediary) antara pihak-pihak yang mengalami surplus unit dan pihak lain yang menalami kekurangan dana (defisit unit). Melalui bank, kelebihan dana tersebut disalurkan kepada pihak lain yang memerlukan dan memberikan manfaat bagi kedua belah pihak. Dengan prinsip ini terjadi hubungan bukan sebagai debitur dan 
kreditur, melainkan terjadi hubungan kemitraan antara penyandang dana (shohibul maal) dengan pengelola dana (mudharib). Oleh karena tingkat pendapatan laba bank syariah bukan saja berpengaruh terhadap tingkat bagi hasil untuk para pemegang saham, tetapi juga berpengaruh terhadap kesejahteraan dan bagi hasil dapat diberikan kepada nasabah penyimpan dana. Dengan demikian, kemampuan manajemen untuk melaksanakan fungsinya sebagai penyimpan harta, pengusaha dan manajer investasi profesional akan sangat menentukan kualitas usahanya sebagai lembaga perantara dan kemampuannya menghasilkan laba.

Disamping hubungan antara shohibul maal dan mudharib dengan menggunakan sistem bagi hasil, bank syariah dalam menjalankan fungsinya sebagi mudharib menawarkan produkproduk yang terikat dengan ketentuan syariah dengan diawasi oleh Dewan Pengawas Syariah (DPS). Dengan demikian jenis-jenis dan istilah-istilah produk yang digunakan adalah istilah yang bersumber dari syariah. Hal ini berdampak pada kurang familiarnya pemahaman dan pengetahuan masyarakat luas. Karena itu, program inklusi keuangan pada bank syariah menjadi tujuan ganda, yakni selain dalam upaya akses masyarakat kepada perbankan syariah sekaligus juga memahamkan (literasi) masyarakat akan produk-produk yang berlabelkan dan bertata cara sesuai yang diatur dalam syariah.

Secara makro tujuan pembiayaan pada bank syariah adalah: (1) Peningkatan ekonomi umat, artinya masyarakat yang tidak dapat akses secara ekonomi, dengan adanya pembiayan mereka dapat melakukan akses ekonomi; (2) Tersedianya dana bagi peningkatan usaha, yakni untuk pengembangan usaha membutuhkan dana tambahan. Dana tambahan ini dapat diperoleh dari pembiayaan. Pihak surplus dana menyalurkan kepada pihak yang minus dana; (3) Meningkatkan produktivitas dan memberi peluang bagi masyarakat untuk meningkatkan daya produksinya, membuka lapangan kerja baru.

Dari sisi masyarakat maupun penyedia jasa terdapat beberapa penyebab, diantaranya adalah masih banyak masyarakat yang berpenghasilan rendah, jarak yang jauh ke lokasi kantor bank terdekat, mahalnya biaya untuk transaksitransaksi dalam volume yg kecil, informasi yang masih terbatas, tingkat pengetahuan keuangan yang rendah, produk yang kurang sesuai serta faktor psikologi, image dan budaya ditambah dengan antrian yang panjang. Sedangkan dari pihak penyedia jasa keuangan berbagai kendala tersebut meliputi pendirian kantor cabang bank mahal, persyaratan yang ditetapkan oleh regulator yang sangat ketat, proses yang kompleks dan formalitas yang tinggi.

\section{Konsep Inklusi Keuangan}

Inklusi keuangan adalah

keterbukaan penyediaan akses dan penggunaan beragam layanan keuangan yang nyaman dan terjangkau. Inklusi keuangan mencakup layanan keuangan yang berkelanjutan, relevan, hemat biaya dan bermakna bagi masyarakat yang kurang terlayani secara finansial terutama penduduk pedesaan (Nwanko, 2014). Layanan tersebut termasuk tabungan, pembiayaan, asuransi dengan cara yang cukup nyaman, handal, dan fleksibel dalam hal akses dan desain.

Inklusi keuangan adalah kegiatan yang bertujuan untuk menghapus semua bentuk hambatan keuangan, untuk mengakses layanan keuangan. Penerapan inklusi keuangan, akan membuka akses orang miskin (orang yang tidak memiliki agunan, tidak memiliki pekerjaan tetap, dapat dipercaya, dan tidak dapat 
memperoleh kredit) ke layanan keuangan. Ini berarti membawa "orang-orang yang tidak bankable kepada lembaga-lembaga keuangan.Tujuan lainnya adalah (1) akses dengan biaya yang wajar untuk berbagai layanan keuangan, termasuk tabungan, deposito, pembayaran dan layanan transfer untuk semua rumah tangga, (2) berkelanjutan keuangan dan kelembagaan untuk memastikan kesinambungan dan kepastian investasi, (3) persaingan untuk memastikan pilihan dan keterjangkauan untuk nasabah.

Inklusi keuangan sebagai kisaran, kualitas dan ketersediaan layanan keuangan bagi yang tidak terlayani secara finansial (World Bank, 2012). Akses layanan yang aman, nyaman dan terjangkau yang tidak memadai bagi kelompok yang kurang beruntung dan rentan lainnya, termasuk penduduk berpenghasilan rendah pedesaan dan tidak berdokumen, yang tidak terlayani atau dikeluarkan dari formal sektor keuangan (TAFF, 2011).

Indikator yang dapat dijadikan ukuran sebuah negara dalam mengembangkan inklusi keuagan adalah: (1) Ketersediaan/akses, yaitu kemampuan penggunaan jasa keuangan formal dalam hal keterjangkauan fisik dan harga; (2) Penggunaan, kemampuan penggunaan aktual produk dan jasa keuangan (antara lain keteraturan, frekuensi dan lama penggunaan); (3) Kualitas, apakah atribut produk dan jasa keuangan telah memenuhi kebutuhan pelanggan; (4) Kesejahteraan, dampak layanan keuangan terhadap tingkat kehidupan pengguna jasa.

Pendalaman sektor keuangan (financial deepening) merupakan sebuah termin yang digunakan untuk menunjukkan terjadinya peningkatan peranan dan kegiatan dari jasa-jasa keuangan terhadap ekonomi. Kedalaman sistem keuangan suatu negara akan meningkatkan pertumbuhan ekonomi karena dapat mengalokasikan dana secara efektif ke sektor-sektor potensial, menimimalkan resiko dengan diversifikasi produk keuangan, meningkatnya faktor produksi dan meningkatkan efisiensi dari penggunaan faktor produksi tersebut yang pada akhirnya meningkatkan investasi atau marginal produktivitas akumulasi modal dengan penggunaan yang semakin efisien. Suatu perekonomian yang sehat dan dinamis membutuhkan sistem keuangan yang mampu menyalurkan dana secara efisien dari masyarakat yang memiliki dana lebih ke masyarakat yang memiliki peluang-peluang investasi produktif.

Meski demikian, industri keuangan yang berkembang sangat pesat belum tentu disertai dengan akses keuangan yang memadai. Padahal, akses layanan keuangan merupakan syarat penting keterlibatan masyarakat luas dalam sistem perekonomian. Seberapa besar kesempatan masyarakat untuk dapat megakses dan menggunakan jasa keuangan, mencerminkan tingkat keuangam inklusif dalam ekonomi tersebut (Azwar, 2017).

Pada G20 Pittsbugh Summit 2009, anggota G20 sepakat akan perlunya peningkatan akses keuangan bagi kelompok ini yang dipertegas pada Toronto Summit tahun 2010, dengan dikeluarkannya 9 Principles for Innovative Financial Inclusion sebagai pedoman pengembangan keuangan inklusif. Prinsip tersebut adalah leadership, diversity, innovation, protection, empowerment, cooperation, knowledge, proportionality, dan framework (Bank Indonesia, 2014). Sejak saat itu banyak forum-forum internasional yang memfokuskan kegiatannya pada keuangan inklusif seperti Consultative Group to Assist the Poor (CGAP), World Bank, APEC, Asian Development Bank (ADB), AFI, Financial Action Task Force (FATF), termasuk negara berkembang dan Indonesia (Bank Indonesia, 2014).

Sejak tahun 2000-an, keuangan inklusif telah secara luas digunakan sebagai 
fokus utama kebijakan di banyak pemerintahan dan bank sentral untuk membangun negaranya. Di India, keuangan inklusif menekankan pada proses untuk memastikan bahwa akses terhadap sistem jasa keuangan dan kredit yang memadai bagi masyarakat miskin dengan biaya yang terjangkau (Rangrajan Committee, 2008). Di Indonesia, keuangan inklusif menjadi strategi nasional untuk mendorong pertumbuhan ekonomi melalui distribusi pendapatan yang merata, penurunan tingkat kemiskinan, dan stabilitas sistem keuangan (Hadad, 2010). Hak setiap individu dijamin untuk dapat mengakses seluruh cakupan kualitas jasa keuangan dengan biaya yang terjangkau. Target dari kebijakan ini sangat memperhatikan masyarakat miskin berpendapatan rendah, masyarakat miskin produktif, pekerja migran, dan masyarakat yang hidup di pelosok (Bank Indonesia, 2014) Sederhananya, beberapa penelitian yang ada saat ini telah menghubungkan paling tidak tiga poin keuangan inklusif yaitu akses, kelompok masyarakat, dan sistem keuangan (Demirgüç-Kunt et al., 2008; Sarma dan Pais, 2008; Sarma, 2008; Demirgüç-Kunt dan Klapper, 2012).

Upaya untuk meningkatkan financial inclusion dan menurunkan financial exclusion dari berbagai belahan dunia dilakukan dalam dua pendekatan, yaitu secara komprehensif dengan menyusun suatu strategi nasional seperti Indonesia, Nigeria, Tanzania dan melalui berbagai program terpisah, misalnya edukasi keuangan seperti yang dilakukan oleh pemerintah Amerika Serikat paska krisis 2008. Secara umum, pendekatan melalui suatu strategi nasional mencakup 3 (tiga) aspek, yaitu penyediaan sarana layanan yang sesuai, penyediaan produk yang cocok, responsible finance melalui edukasi keuangan dan perlindungan konsumen. Penerapan keuangan inklusif umumnya bertahap dimulai dengan target yang jelas seperti melalui penerima bantuan program sosial pemerintah atau pekerja migran sebelum secara perlahan dapat digunakan oleh masyarakat umum.

Strategi keuangan inklusif di Indonesia bukanlah sebuah inisiatif yang terisolasi, sehingga keterlibatan dalam keuangan inklusif tidak hanya terkait dengan tugas Bank Indonesia, namun juga regulator, kementerian dan lembaga lainnya dalam upaya pelayanan keuangan kepada masyarakat luas. Melalui strategi nasional keuangan inklusif diharapkan kolaborasi antar lembaga pemerintah dan pemangku kepentingan tercipta secara baik dan terstruktur.

\section{Digital Theory}

Digitalisasi adalah trend modern yang telah diperdebatkan sejak tahun 1980an, saat itu komputer rumah mulai diperkenalkan ke pasar konsumen, yang kemudian membuka saluran baru bagi konsumen menjadi lebih komunal dan sadar akan isu-isu terbaru. Teknologi modern dan digitalisasi telah menghilangkan hambatan dari masyarakat modern, terutama waktu, ruang, perolehan data dan keterlibatan yang memungkinkan konsumen memiliki lebih banyak kebebasan berinteraksi dengan pihak lain tanpa memandang waktu atau ruang (Koiranen, Rasanen \& Sodegarrd, 2010). Digitalisasi dapat didefinisikan sebagai penggunaan teknologi digital untuk model bisnis baru dan memberikan peluang baru yang menghasilkan nilai. Hal ini merupakan bisnis digital dan integrasi teknologi digital ke dalam kehidupan sehari-hari (Gartner, 2016). Digitalisasi adalah peluang bagi perusahaan dan organisasi untuk meningkatkan aktivitas bisnis mereka.

Di era digitalisasi dan otomatisasi banyak pekerjaan kantor dapat diproduksi lebih efisien dan dengan biaya rendah (Schinkel, 2000). Digitalisasi dapat dilihat sebagai peluang untuk meningkatkan hubungan pelanggan, proses bisnis, 
menciptakan dan mengadaptasi model bisnis baru (Schumann \& Tittmann, 2015).

Di sektor keuangan termasuk perbankan, digitalisasi dilihat sebagai pengembangan metode kerja dan lingkungan kerja. Kemajuan dalam teknologi informasi dan sistem komputer dilihat sebagai peningkatan positif, yang menjadikan bekerja lebih efisien dan cepat. Konsensus umum adalah bahwa karena digitalisasi, pelanggan akan menjadi lebih mandiri dan lingkungan kerja berubah menjadi lingkungan yang lebih digital, yang dapat mengubah seluruh organisasi. Telecommuting dan bekerja jarak jauh dari kantor akan menjadi lebih banyak metode kerja saat ini dan di masa depan, keterampilan digital menjadi semakin penting dan menjadi kebutuhan tenaga kerja (Finanssialan keskusliitto, 2015).

Teknologi digital telah menjadi transformasi di banyak perusahaan, dimana mereka telah menciptakan berbagai macam implementasi untuk mencapai manfaat penuh digitalisasi sektor bisnis, termasuk bisnis perbankan. Transformasi digital membutuhkan perubahan pada banyak elemen praktek perusahaan, seperti manajemen dan stuktur organisasi. Karena transformasi digital adalah perubahan signifikan dalam struktur organisasi, maka akan logis untuk menggabungkannya dengan strategi bisnis yang ada (Matt, Hess dan Benlian, 2015).

McKinsey (2014) mengutip artikel Smaje \& Willmot yang mengatakan bahwa perusahaan harus melalui 7 tonggak yang berbeda agar bertahan hidup dan berhasil dalam dunia digitalisasi. Mereka mengamati beberapa perusahaan berbeda yang telah berhasil dalam dunia digitalisasi dan menciptakan peta jalan mereka sendiri tentang bagaimana bertahan hidup dan berhasil dalam dunia bisnis saat ini. Tujuh langkah tersebut jika digambarkan adalah sebagai berikut:

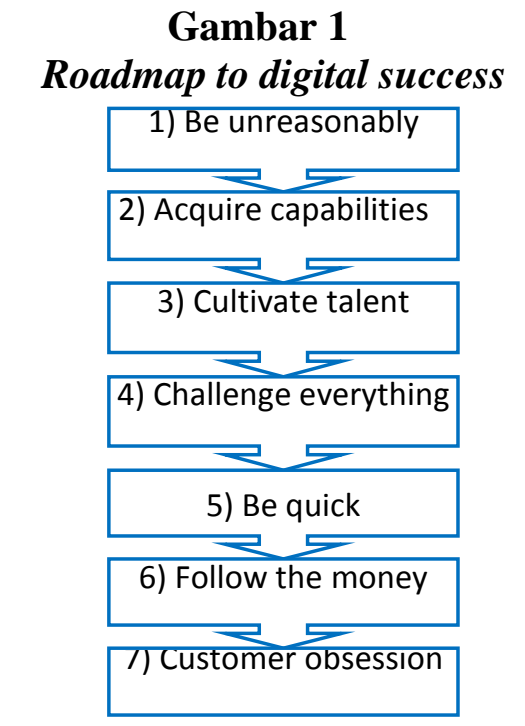

(McKinsey 2014, cited 24.11.2016)

Ketujuh langkah ini juga dapat dimanfaatkan oleh sektor keuangan untuk mendapatkan nilai digital beberapa poin kunci sudah dapat dilihat dalam pengembangan sektor perbankan, seperti meningkatnya minat dalam obsesi pelanggan. Misalnya, memperoleh kemampuan digital dan bakat mentah dari industri lain selain perbankan dapat meningkatkan proposisi nilai baru untuk industri dan bahkan saluran baru bagaimana bank dapat berinteraksi dengan nasabah.

Salah satu teknologi digital yang banyak digunakan dalam dunia bisnis adalah cloud computing. Dalam dekade terakhir cloud computing membawa revolusi teknologi dan pergeseran paradigma di sektor teknologi informasi dan komunikasi (ICT). Cloud computing mengalami adopsi besar-besaran di hampir setiap domain kehidupan manusia (K. Bilal, S.U.R. Malik, S.U. Khan, A.Y. Zomaya, 2014). Pusat data, tulang punggung dan arsitektur sumberdaya yang mendasari komputasi terus berkembang dalam ukuran dan jumlah untuk memenuhi tuntutan sumber daya yang meningkat (K. Bilal at al, 2014). Tingkat data yang semakin meningkat dari perangkat Internet of Thing (IoT) akan memberlakukan tantangan lebih 
lanjut pada infrastruktur komputasi maya. IoT adalah teknologi baru yang memperluas koneksi internet ke perangkat yang tertanam dengan sensor, aktuator, dan tag RFID (W. Shi, J. Cao, 2016). Umumnya, Internet terdiri dari ribuan jaringan yang saling terkait, dengan masing-masing jaringan menyediakan akses ke sebagian kecil pengguna akhir. Bahkan jaringan terbesar biasanya diakses oleh hanya sekitar $5 \%$ pengguna (E. Nygren at al, 2010). Tahun 2020 akan menghasilkan jumlah data yang masif (O. Fratu, at al, 2015). Transfer data antar-jaringan menyebabkan peningkatan latensi dan kemacetan. Sesuai statistik yang dikumpulkan oleh Akamai, lebih dari 650 jaringan berpartisipasi dalam mencapai $90 \%$ dari semua akses traffic. Permintaan ke atau dari cloud dapat memakan waktu beberapa milidetik hingga detik untuk melakukan perjalanan dari klien ke penyedia layanan cloud (K. Ha, P. Pillai at al, 2013). Bahkan sedikit keterlambatan dalam permintaan pengguna dapat menyebabkan hilangnya pelanggan dan pendapatan. Sebuah survei yang dilakukan oleh Forester menyimpulkan bahwa sebagian besar pembeli online telah menyarankan waktu respon situs web sebagai faktor utama dalam memberikan umpan balik kepuasan pelanggan mereka.

\section{Gambar 2}

\section{Edge computing architecture}

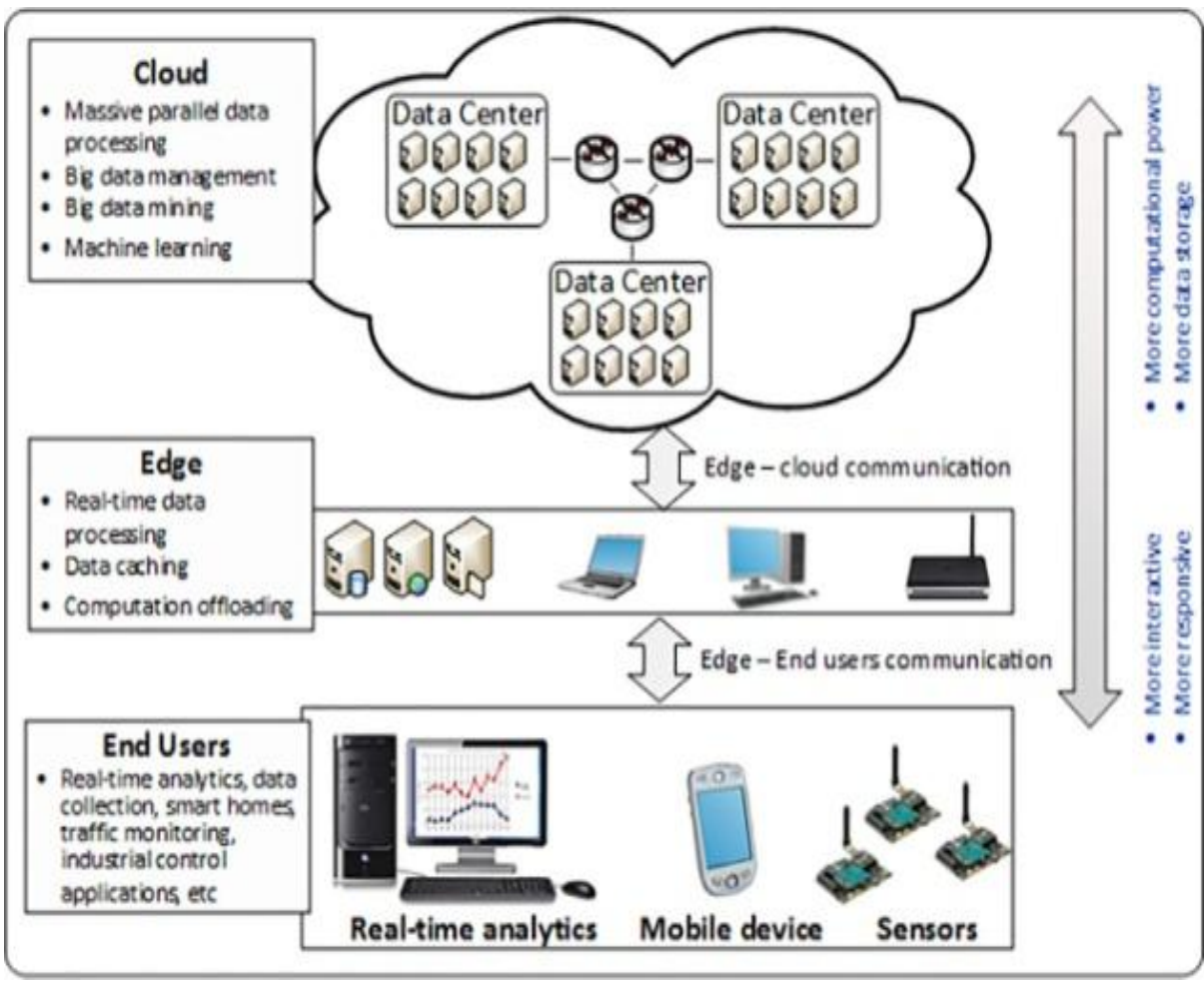

Sumber: Kashif Bilal, Osman Khalid, Aiman Erbad, Samee U. Khan. Computer Networks 130 (2018) 94-120. (2017)

Survei juga menemukan bahwa lebih dari $40 \%$ pelanggan hanya dapat menunggu 3 detik untuk memuat laman sebelum meninggalkan situs web (E. Nygren, R.K. Sitaraman, J. Sun, 2010). Dalam survei lain yang dilakukan oleh IDC, dilaporkan bahwa peningkatan 
kinerja dan reliabilitas layanan akselerasi aplikasi perusahaan Akamai menghasilkan peningkatan tahunan dari $0, \$ 2$ juta hingga $\$ 3$ juta (A. Giordano, G. Spezzano, 2016). Oleh karena itu, penyebaran konten di ISP lokal (hulu jaringan) sangat penting untuk daerah dengan konektivitas rendah dan waktu respon yang tinggi.

Evolusi teknologi informasi dan komunikasi telah melahirkan globalisasi yang dapat mempersingkat jarak dan waktu untuk berkomunikasi melalui digital elektronik. Teori digital adalah sebuah konsep pemahaman dari perkembangan zaman mengenai teknologi dan sains, dari semua yang bersifat manusia menjadi otomatis, dan dari semua yang bersifat rumit menjadi ringkas. Digital adalah sebuah metode yang kompleks namun fleksibel yang membuatnya menjadi sesuatu yang pokok dalam kehidupan manusia. Teori digital selalu berhubungan dengan media, karena media adalah sesuatu yang terus berkembang. media baru adalah media yang terbentuk dari interaksi manusia dengan teknologi. Diantara media modern tersebut adalah internet, mobile phone, social network, dan sebagainya. Media ini menjadi payung kehidupan yang menghubungkan manusia dengan manusia, manusia dengan teknologi di abad ini.

Internet sangat berpengaruh bagi kehidupan manusia, ditambah lagi dengan terus berkembangnya inovasiinovasi teknologinya. Media internet dapat digunakan untuk berbagai kegiatan bisnis (e-commerce), pendidikan (elearning), perbankan (m-banking), termasuk jejaring internet yang saat ini dijadikan media komunikasi seperti facebook, twitter, yahoo massenger dan sebagainya.
Digitalisasi perbankan dapat menekan efisiensi. Digitalisasi perbankan dapat menurunkan biaya operasional perbankan hingga $25 \%$, bahkan mungkin lebih (McKinsey, 2016). Merupakan investasi jangka panjang, yang dapat menjangkau pasar yang lebih luas dengan menurunkan anggaran investasi pembukaan cabang baru, cabang pembantu dan kantor kas kecil. Ada dua cara yang dapat dilakukan perbankan. Pertama, digitalisasi layanan agar dapat memberikan pelayanan yang lebih cepat, murah, dan mudah ke nasabah. Misalnya, membuka rekening digital melalui telepon pintar. Kedua, mengintegrasikan kegiatan perbankan dengan kehidupan nasabah sehari-hari. Seperti melalui aplikasi "Home Connect" untuk memudahkan calon klien menaksir harga rumah yang akan dibelinya berdasarkan harga ratarata di kawasan tersebut.

Internet telah membuat revolusi dunia komputer dan dunia komunikasi yang tidak pernah diduga sebelumnya. Penemuan telegram, telepon, radio, dan komputer merupakan rangkaian kerja ilmiah yang menuntun menuju terciptanya internet yang lebih terintegrasi dan lebih berkemampuan dari pada alat-alat tersebut. Internet memiliki kemampuan penyiaran ke seluruh pelosok dunia, memiliki mekanisme diseminasi informasi, dan sebagai media untuk berkolaborasi dan berinteraksi antara individu dengan komputernya tanpa dibatasi oleh kondisi geografis. Resolusi dari internet menciptakan image baru, yaitu sebuah new media yang kebanyakan orang sudah menggunakannya pada saat ini. Ini merupakan sebuah implementasi dari perluasan ikon yang bersumber pada internet. 
Metodologi

Dalam mencapai tujuan studi ini, penulis mengidentifikasi sejumlah metode yang dapat digunakan dalam pengumpulan dan menganalisis data. Data dikumpulkan dan dianalisa menghasilkan studi otoritatif dan mencapai tujuan yang diinginkan. Studi dilakukan menggunakan metode data koleksi melalui riset perpustakaan. Data yang diperoleh adalah dari bahan yang terdiri dari literatur berbahasa Arab maupun inggris, perbankan Islam, jurnal dan materi lainnya di perpustakaan atau pusat sumber pengetahuan.

Untuk menganalisa data, ketiga metode data analisis telah digunakan yaitu metode induktif, deduktif, dan komparatif. Metode induktif adalah cara menganalisis data untuk mencari bukti dari argumen yang spesifik untuk mencapai proposisi umum. Metode ini digunakan untuk membuat mendefinisikan dan menjelaskan fungsi dan pengembangan internet, khususnya di perbankan syariah.

Metode deduktif adalah cara menganalisis data dan melakukan penulisan pada fakta-fakta yang umum untuk fakta-fakta sifat tertentu. Metode ini digunakan untuk menganalisis perbuatan dan fatwa kontemporer terkait dengan transaksi di internet perbankan.

Metode komparatif adalah membuat perbandingan antara data yang dikumpulkan untuk memperoleh kesimpulan yang akurat dengan penelitian masalah. Metode ini dengan membuat perbandingan antara ketentuan yang ada dalam bertindak dengan fatwa atau buku-buku fiqih kontemporer.

Untuk melengkapi analisis data digunakan data hasil survey kuantitatif dari 200 usaha skala kecil (UMKM) sektor riil yang telah mengakses dan mengunakan transaksi dengan perbankan syariah di lima kabupaten dan kota sewilayah cirebon.

\section{Pembahasan \\ Analisis Data}

Seiring dengan pertumbuhan ekonomi global, kemajuan teknologi tak terelakkan. Para ahli terus berinovasi menciptakan media yang dapat mempermudah kehidupan manusia. Digital economy merupakan suatu perkembangan dan pertumbuhan ekonomi yang menggunakan teknologi digital atau internet sebagai medianya dalam berbagai kegiatan baik berkomunikasi, kolaborasi maupun kerjasama antar perusahaan ataupun individu yang dapat mendatangkan profit dalam perekonomian. Kegiatan tersebut dapat meliputi berbagai area yang luas, termasuk untuk jasa bisnis perbankan. Dengan keberadaan digital ekonomi akan mendorong pertumbuhan ekonomi dan meningkatkan daya saing produk dan jasa baik di level mikro maupun makro.

Petumbuhan era ekonomi digital berkembang sangat cepat. Semua transaksi akan menggunakan basis teknologi, dan semakin banyaknya variasi model bisnis ekonomi digital yang berkembang untuk mendorong terciptanya pembagian ekonomi diantara pelaku bisnis. Perbankan pun bergerak maju dan berkolaborasi untuk meningkatkan sistem dan strategi agar masyarakar dapat membuktikan serta merasakan bahwa bertransaksi dengan bantuan teknologi itu mudah. Persaingan antar bank dan institusi keuangan sudah memasuki babak baru dalam teknologi aplikasi yang merupakan implikasi perkembangan bisnis perbankan di era digital economy.

Peluang dan harapan perbankan di era digital economy berada pada digital banking. Digital banking akan 
membuat nasabah merasa aman dan nyaman, sehingga perbankan syariah tetap menjadi pilihan utama dalam melakukan transaksi dan kegiatan keuangan. Masa depan dunia perbankan di era digital ini sangat cerah terutama apabila perbankan memperhatikan teknologi dan terus berinovasi untuk selalu memberi kemudahan yang kenyamanan bagi para nasabah. Apabila hal ini terus dilakukan oleh sektor perbankan syariah, maka di masa yang akan datang perbankan syariah sudah amat dekat dengan masyarakat. Masa depan cerah perbankan syariah akan beriringan dengan masa depan teknologi yang semakin maju.

Perbankan syariah sebagai salah satu sektor ekonomi yang menjadi roda perputaran dana di suatu negara harus berkembang dan mengikuti kebutuhan pasar. Perbankan syariah harus selalu menjadi pilihan utama individu dalam melakukan kegiatan pembayaran dan kegiatan ekonomi lainnya. Untuk mencapai target dan tujuan tersebut, perbankan haruslah melakukan inovasi tiada henti sesuai dengan kebutuhan dan mempermudah nasabah untuk melakukan segala kegiatan ekonominya. Teknologi aplikasi dalam perbankan dinamakan dengan digital banking yang merupakan layanan perbankan dengan memanfaatkan teknologi digital untuk memenuhi kebutuhan nasabah demi mewujudkan ekonomi digital seperti yang dicita-citakan. Digital banking yang telah berkembang sampai saat ini yaitu seperti ATM, internet banking, mobile banking, video banking, phone banking dan SMS banking. Beberapa bank juga telah meluncurkan layanan keuangan tanpa kantor (branchless banking) yang utamanya ditujukan untuk masyarakat yang belum memiliki akses ke perbankan (unbanked).
Perkembangan digital telah menyentuh seluruh aspek kehidupan termasuk sektor ekonomi perbankan. Dengan berkembanya digital ekonomi memudahkan manusia untuk melakukan kegiatan perbankannya tanpa harus datang ke kantor bank terkait. Jika melihat mundur ke belakang, dahulu sektor perbankan mengharuskan setiap nasabahnya untuk datang langsung ke kantor cabang untuk setiap transaksi. Mulai dari melakukan setoran tunai hingga tarikan tunai, semua itu dilakukan dengan manual dan mengharuskan setiap nasabah untuk datang dan berlama lama antri untuk dapat melakukan transaksinya. Seiring berkembangnya zaman dan juga teknologi, manusia akan melakukan berbagai cara untuk menghemat waktunya di era globalisasi ini.

Penemuan yang luar biasa dari perbankan ialah ditemukannya ATM (Automatic Teller Machine), penemuan ini membuat setiap nasabah yang ingin melakukan tarikan tunai untuk tidak harus datang ke teller dan menunggu berlama-lama. Saat ini, ATM tidak hanya dapat memenuhi kebutuhan transaki nasabah untuk melakukan tarikan tunai, tetapi dapat juga melakukan transaksi pembayaran, transfer di mesin ini. Bahkan saat ini sudah ada ribuan ATM yang dapat melakukan setoran tunai yang semakin memudahkan nasabah untuk melakukan setiap transaksi. Hal ini membuat perbankan di Indonesia tidak terlalu gencar melakukan perluasan jaringan dengan membuka kantor cabang. Berdasarkan informasi dari Statistik Perbankan Indonesia yang dikeluarkan oleh Otoritas Jasa Keuangan (OJK), jumlah kantor bank umum per Juli 2017 tercatat sebanyak 32.659 unit kantor. Jumlah tersebut menyusut $0,3 \%$ dibandingkan dengan kondisi pada 
periode yang sama pada tahun lalu yakni sebanyak 32.772 unit kantor. Sementara itu perkembangan mesin ATM di Indonesia selama 3 tahun terakhir ini terbilang fluktuatif dibandingkan dengan 5 tahun ke belakang. Sementara itu, menurut data Bank Indonesia (BI), jumlah mesin ATM juga hanya tumbuh tipis. Terhitung Juli 2017, jumlah ATM yang tersebar sebanyak 103.953 unit mesin, jumlah ini hanya bertambah $0,51 \%$ dibandingkan posisi pada akhir tahun 2016.

Seiring dengan berkembangnya teknologi dan juga keunggulan smartphone yang makin berkembang, perbankan syariah mencoba untuk mengikuti perkembangan teknologi itu pula. Langkah pertama yang dilakukan perbankan syariah untuk mengimbangi perkembangan teknologi ialah dengan mengeluarkan jasa sms-banking. Meskipun terdengar kuno, fasilitas dari perbankan ini sempat menjadi salah satu solusi untuk mengirim uang dan melakukan pembayaran di wilayah yang jauh dari mesin ATM. Selain itu ada internet banking yang memudahkan para nasabahnya untuk melakukan berbagai transaksi mulai dari pengecekan saldo hingga membayar tagihan bulanan. Dengan internet banking masyarakat bisa melakukan berbagai transaksi perbankan di berbagai penjuru dunia tanpa terikat waktu dan hanya membutuhkan koneksi internet. Setelah smartphone semakin mudah untuk dimiliki, berbagai bank mulai melirik aplikasi m-banking. Dibandingkan dengan sms-banking dan juga internet banking, m-banking lebih diminati para nasabah. Mereka bisa menggunakan fasilitas m-banking dengan sangat mudah untuk menyelesaikan segala transaksi perbankan.

Perkembangan pengguna $e$ banking di Indonesia sendiri cukup pesat. Otoritas Jasa Keuangan mengungkapkan secara data dan pengguna e-banking cukup meyakinkan. Di mana jumlah pengguna e-banking (SMS banking, phonebanking, mobile banking, dan internet banking) meningkat menjadi $270 \%$, dari 13,6 juta nasabah pada tahun 2012 meningkat menjadi 50,4 juta nasabah pada 2016. Sementara jumlah transaksi pengguna $e$ banking meningkat $169 \%$, dari 150,8 juta transaksi pada tahun 2012 menjadi 405,4 juta transaksi pada tahun 2016. Perkembangan perbankan 3 hingga 5 tahun terakhir ini memang didominasi oleh perkembangan teknologi perbankan menyusul perkembangan digital ekonomi, perbankan semakin memanjakan para nasabahnya dengan melakukan berbagai inovasi agar nasabah dapat melakukan transaksi keuangan tanpa harus kehilangan waktu berlebih.

\section{Digitalisasi Perbankan Syariah}

Kehadiran dan praktek bank syariah di Indonesia sudah hampir tiga dekade, namun perkembangan usahanya masih belum sebanding dengan waktu yang telah dilaluinya. Hingga akhir 2016 pertumbuhan perbankan syariah mencapai 19,67 persen. Sementara pangsa pasar (market share) perbankan syariah berada di angka 5,12 persen. Aset 406,23 Triliun, pertumbuhan 19,79 \%, Dana DPK 325,96 triliun, Total Pembiayaan 281 triliun dengan jumlah nasabah 24 juta nasabah. Pencapaian ini jelas belum sebanding dengan potensi yang dimiliki bangsa ini.

Pada tahun 2017 salah satu bank syariah di lingkungan OJK telah melakukan penelitian yang hasilnya ditemukan bahwa sebenarnya minat masyarakat terhadap perbankan syariah mulai meningkat yang ditunjukkan dengan jumlah rekening dana pihak 
ketiga yang tercatat mencapai 26,57 juta per Oktober 2017 terdiri dari bank umum syariah (BUS) 20,86 juta rekening, unit usaha syariah (UUS) 4,34 juta rekening, dan bank perkreditan rakyat syariah (BPRS) 1,36 juta rekening. OJK juga mencatat total aset keuangan perbankan syariah Indonesia per Oktober 2017 mencapai Rp 406,23 triliun dengan "market share" perbankan syariah mencakup 5,55 persen. Sementara total aset keuangan syariah Indonesia, tidak termasuk saham syariah, mencapai $\mathrm{Rp} \mathrm{1.086,98} \mathrm{triliun} \mathrm{dengan}$ market share keuangan syariah mencakup 8,12 persen (Antara, 15 Desember 2017). OJK akan terus berupaya menjalankan program strategis dalam mengembangkan keuangan syariah, terutama menyangkut optimalisasi promosi keuangan syariah untuk meningkatkan literasi dan preferensi masyarakat. OJK mendorong industri untuk mensosialisasikan mengenai pemahaman keuangan syariah mengingat literasi keuangan syariah masih tergolong rendah.

Menurut Nejatullah Siddiqi dalam evaluasinya menegaskan bahwa ada kebutuhan mendasar yang dirasakan mendesak untuk mengevaluasi apa yang telah terjadi selama tiga dekade terakhir di bidang perbankan dan keuangan Islam. Lebih penting daripada berfokus pada pertumbuhannya, kinerja komersial dan pangsa pasar adalah kebutuhan untuk mengevaluasi dalam hal kontribusinya untuk memperkenalkan dan mempromosikan pemahaman aspek ekonomi dan keuangan dari cara hidup Islam secara keseluruhan. Sebuah survei tentang keadaan seni di bidang perbankan dan keuangan Islam dalam teori dan praktek diharapkan dapat memenuhi kebutuhan itu. Karena itu dalam prakteknya permasalahan yang masih dihadapi oleh sektor keuangan syariah antara lain keterbatasan suplai produk syariah; keterbatasan akses akan produk keuangan syariah; masih belum optimalnya tingkat literasi keuangan syariah dan tingkat utilitas produk keuangan syariah; keterbatasan sumber daya manusia; perlunya optimalisasi koordinasi dengan para pemangku kepentingan; serta perlunya kebijakan jasa keuangan yang selaras dan dapat saling mendukung perkembangan seluruh sektor keuangan syariah.

Transformasi digitalisasi layanan perbankan syariah adalah sebuah keniscayaan. Antisipasinya adalah legacy untuk bisa bertahan. Lembaga bisnis bisa saja memilih apakah menjadi pemain dalam perubahan atau hanya menjadi penonton perubahan. Jika jatuh pilihannya pada memilih menjadi pemain perubahan, konsekuensinya harus siap dengan perubahan mindset dan perubahan peran dan tanggung jawab atas pekerjaan baru serta siap pula menghadapi kompetisi dan keilmuan yang baru.

Hubungan intensitas sosialisasi yang tinggi oleh perbankan syariah dapat mempengaruhi masyarakat secara umum, dimana fungsi yang terkandung adalah menarik perhatian dan mampu menarik calon nasabah baru sekaligus mempertahankan kepercayaan masyarakat terhadap perbankan syariah.

Fasilitas internet dan beragam media sosial (facebook, twitter, instagram dan yang lainnya) dapat dimanfaatkan untuk kepentingan edukasi dan sosialisasi ekonomi syariah, terutama bank syariah yang memiliki sistem dan produk yang berbeda dengan bank konvensional. Di era digital seperti saat ini bentuk media sudah beralih ke format online karena mudah diakses oleh siapa saja yang membutuhkan informasi. Masyarakat juga dengan mudahnya berbagi informasi (share) akun sosialnya 
masing-masing sehingga informasi dan pengetahuan tentang ekonomi dan perbankan syariah akan mudah diterima oleh masyarakat. Setidaknya upayaupaya tersebut dapat menigkatkan pengetahuan masyarakat akan seluk beluk keuangan syariah yang selama ini mereka belum memahaminya. Selain itu, informasi yang cenderung negatif terhadap perbankan syariah dapat diluruskan, lewat media digital tersebut mereka memperoleh pencerahan tentang persoalan-persoalan bank syariah yang selama ini masih dipandang sebelah mata, yang pada akhirnya mereka dapat memutuskan untuk beralih dari sistem konvensional ke sistem bank syariah yang ternyata memberikan kemaslahatan bagi semua pihak.

Di sisi lain, dengan adanya era digital, sumberdaya yang tidak dimanfaatkan (unutilized) menjadi semakin bermanfaat. Sebagai contoh misalnya; hotel yang semula sepi pengunjung ketika dibantu pemasarannya dengan aplikasi menjadi semakin penuh. Motor dan mobil yang semula hanya digunakan sebagai kendaraan pribadi, sejak ada transportasi online kini dapat dimanfaatkan menjadi kendaraan alternatif. Bluebird yang telah eksis selama 20 tahun pun merasa terancam dengan keberadaan tranformasi taksi online.

Beberapa kondisi perbankan syariah yang mendorong untuk mengoptimalkan penggunaan teknologi digital antara lain bahwa berbedanya konsep dan sistem perbankan syariah dalam hal bertransaksi membutuhkan cara inklusi dan literasi tersendiri. Masyarakat butuh literasi agar memiliki pemahaman yang mudah dan benar bahwa sistem perbankan syariah lebih menguntungkan dibanding dengan sistem konvensional. Karena literasi merupakan serangkaian proses atau aktivitas untuk meningkatkan pengetahuan (knowledge) dan menambah wawasan, keyakinan (confidence), dan keterampilan (skills) konsumen dan masyarakat luas sehingga mereka mampu mengelola keuangannya secara lebih baik.

Terjadinya perubahan perilaku masyarakat menggunakan cara digital yang memungkinkan untuk melakukan cara berbisnis yang lebih mudah dan praktis, cepat, aman, tidak antri, simpel dan lebih hemat biaya dan tidak dibatasi oleh jarak (borderless) serta lebih tailor made. mendengarkan konsumen dengan lebih seksama merupakan kunci untuk terus bersaing. Khususnya, di tengah kompetisi yang semakin sengit dan pergeseran pilihan cara pembayaran yang kian menjadi tantangan industri perbankan syariah.

Masyarakat sudah familiar dengan penggunaan internet melalui telepon seluler dan komputer dengan penetrasi pengguna internet terbesar adalah kelompok mahasiswa (87\%) dan pelajar (69\%). Sehingga kelompok inilah yang diprediksi akan menyumbang pendapatan terbesar bagi industri perbankan dan layanan keuangan 10 tahun mendatang (McKinsey, 2015). Tren ini menunjukkan adanya potensi pertumbuhan adopsi layanan keuangan digital oleh masyarakat Indonesia melalui telpon seluler pada kelompok masyarakat dengan usia produktif, mahasiswa, dan pelajar.

Layanan teknologi yang menjadi andalan bank adalah online banking. Ekspansi perbankan syariah melalui unit layanan syariah (office channeling) di kantor cabang membuat online banking menjadi standar pelayanan. Online banking dapat menjadi nilai tambah bagi produk bank syariah. Di daerah pedesaan inovasi teknologi pun dapat menjangkau keuangan mikro atau sebagai alat untuk 
membantu bisnis usaha kecil dan menengah. Sudah terjadi kompetisi perbankan mengarah ke branchless banking untuk menjangkau masyarakat di daerah.

Kemampuan digital yang dapat menciptakan nilai tersebut dalam prakteknya dapat digunakan hal-hal berikut: Pertama, teknologi digital meningkatkan konektivitas bank tidak hanya dengan pelanggan tetapi juga dengan karyawan dan pemasok. Ini memanjang dari interaktivitas online dan solusi pembayaran untuk fungsi dan peluang seluler guna meningkatkan brand bank di media sosial. Kedua, penarikan digital pada data besar dan analisis canggih untuk memperluas dan menyempurnakan pengambilan keputusan. Analisis semacam ini sedang digunakan oleh bank paling inovatif di banyak bidang, termasuk penjualan, desain produk, harga dan underwriting serta desain pengalaman pelanggan yang benar-benar luar biasa. Ketiga, pemrosesan langsung, yakni mengotomatisasi dan mendigitalkan sejumlah proses yang berulang, bernilai rendah dan beresiko rendah. Aplikasi proses misalnya meningkatkan produktivitas dan mempfasilitasi kepatuhan terhadap peraturan, sementara proses pencitraan dan pemrosesan langsung mengarah pada alur kerja yang lebih ringan dan tanpa kertas. Keempat, digitalisasi adalah sarana untuk mendorong inovasi di seluruh produk dan model bisnis, termasuk pemasaran sosial dengan dukungan crowd sourced serta model bisnis digitally centered.

\section{Hambatan dan Tantangan}

Otoritas Jasa Keuangan (OJK) menuturkan bahwa setidaknya terdapat tiga tantangan yang dihadapi perbankan di Indonesia dalam pelayanan digital banking, yakni evaluasi uji coba layanan digital banking Bank Indonesia (BI) terkait dengan sistem informasi bank, ketersediaan jaringan, dan edukasi serta perlindungan konsumen.

Selain ketiga tantangan yang terkait dengan digital Bank Indonesia di atas, dalam praktek digital perbankan masih menghadapi juga berbagai hambatan yang membuat perkembangan digital ekonomi perbankan syariah terganggu, diantaranya infrastruktur jaringan yang kurang luas sehingga belum dapat diakses semua orang. Masih rendahnya minat masyarakat Indonesia yang melakukan kegiatan ekonomi digital, baru sekitar 35\% masyarakat Indonesia yang melakukan transaksi digital keuangan. Kontribusi bisnis di sektor digital masih minim terhadap Produk Domestik Bruto (PDB). Tantangan berikutnya adalah dihadapi para CEO bank untuk mengambil kepemimpinan dalam pengembangan dan pelaksanaan program perubahan menyeluruh yang secara bersamaan membahas budaya, sistem, dan kemampuan yang diperlukan.

Beberapa tantangan digital ekonomi terhadap perkembangan bisnis perbankan yaitu seperti pada bagian keamanan atau sekuriti. Dengan semakin canggihnya teknologi keamanan seiring pula dengan makin canggihnya teknologi pencurian di ranah digital. Salah satu kejahatan yang paling sering terjadi yaitu pencurian identitas atau phising. Phising merupakan pencurian data penting milik orang lain seperti nama lengkap, alamat tempat tinggal, dan nomor telepon yang dipergunakan untuk membobol akun nasabah. Semua itu dilakukan oleh pengguna (user) sendiri yang tidak bertanggung jawab, seperti munculnya tindak kriminal baru berupa ancaman peretasan website untuk mencuri datadata perusahaan, maraknya penipuan berkedok bisnis online dan sebagainya. 
Perkembangan teknologi dan internet yang semakin cepat dan gesit sebenarnya sangat membantu bagi efektifitas dan efisiensi dalam upaya inklusi dan literasi keuangan operasional perbankan syariah. Namun berbagai hambatan baik teknis maupun operasional tersebut harus dimaknai sebagai tantangan dan harus dijadikan sebagai pemicu untuk berkreasi dan menghasilkan sesuatu yang akan membantu pekerjaan manusia lebih teratur dan terarah.

Dunia digital sudah memasuki industri keuangan seperti e-commerce yang semakin meningkat transaksinya dari hari ke hari. Masyarakat di era digital ini menginginkan dan menyukai kemudahan. Mereka dengan terbuka akan menerima segala keterbukaan dan kemajuan teknologi. Di industri keuangan sendiri sudah ada berbagai uang elektronik yang dimaksudkan untuk mempermudah berbagai kegiatan manusia sehari hari. Mulai dari uang elektronik yang tertempel di handphone hingga saldo di aplikasi tertentu untuk memudahkan pembayaran. Peluang dan tantangan di era digital ini akan dirasakan oleh semua sektor termasuk industri keuangan dan juga industri perbankan syariah.

Untuk mengatasi berbagai persoalan di atas, setidaknya ada beberapa langkah yang dapat dilakukan oleh perbankan syariah sebagai ikhtiar untuk mengembangkan digital banking tersebut: Pertama, pengalaman konsumen, yakni perusahaan-perusahaan digital harus memberikan kesan terbaik kepada konsumen dalam menggunakan jasanya. Sebab, konsumen di dunia digital sangat mudah berpaling ke perusahaan-perusahaan lain. Kedua, cyber security, yaitu perbankan bersamasama pemerintah harus bekerja sama dalam memberikan keamanan bagi transaksi yang dilakukan. Ketiga, menghubungkan online dengan offline. Keempat, perusahaan juga harus menggunakan analisis berbasis data untuk menentukan kebutuhan, perilaku, dan keinginan konsumen. Kelima, berbagai perusahaan dan pemerintah harus sudah mulai membangun DNA digital. Jadi, pemerintah dan perusahaan harus mengeluarkan regulasi yang mendukung digitalisasi.

Dengan adanya digital bank diharapkan bank dapat mempermudah dalam menyimpan dan menganalisa data nasabah. Sehingga dapat membantu bank untuk menjaga hubungan dengan konsumen, mengatasi keluhan konsumen dengan lebih baik, serta dapat mengembangkan produk atau layanan yang lebih tepat dengan lebih cepat, murah, jelas dan transparan bagi konsumen. Bank lebih efisien karena ridak lagi berinvestasi pada kantor cabang serta nasabah tidak perlu repot ke kantor cabang misalnya untuk transfer uang ke keluarga yang berbeda daerah.

\section{Penutup}

Pangsa pasar bank syariah hingga saat ini masih dalam kategori rendah $(5,12 \%)$. Untuk itu masih perlu kerja keras untuk melakukan inklusi dan literasi keuangan kepada masyarakat sasaran yang belum bankable syariah, selain mempertahankan nasabah yang ada dengan memberikan pelayanan terbaiknya. Perbankan syariah perlu melakukan terobosan-terobosan dengan inovasi-inovasi cerdas untuk memberikan pemahaman dan menstimuli masyarakat agar memiliki preferensi bank syariah sebagai pilihan ekonominya.

Kehadiran teknologi informasi dan komunikasi yang makin pesat dapat membantu untuk tujuan itu, dengan dijadikannya sarana dan media yang 
efektif untuk memperluas akses pasar yang belum tersentuh oleh perbankan syariah. Karena peran dan fungsi bank syariah tidak hanya menjadikan hubungan sebagai debitur dan kreditur, melainkan terjadi hubungan kemitraan antara penyandang dana (shohibul maal) dengan pengelola dana (mudharib) yang berpengaruh terhadap kesejahteraan bagi para pihak. Ekspansi perbankan syariah melalui unit layanan syariah (office channeling) di kantor cabang membuat online banking menjadi standar pelayanan. Online banking dapat menjadi nilai tambah bagi produk bank syariah. Dengan adanya digital bank diharapkan bank dapat mempermudah dalam menyimpan dan menganalisa data nasabah. Sehingga dapat membantu bank untuk menjaga hubungan dengan konsumen, mengatasi keluhan konsumen dengan lebih baik, serta dapat mengembangkan produk atau layanan yang lebih tepat dengan lebih cepat, murah, jelas, dan transparan bagi konsumen.

Tidak dapat dipungkiri bahwa pelayanan melalui digital banking walaupun sangat bermanfaat dan membantu pelayanan bank syariah, dalam prakteknya tetap menghadapi hambatan dan tantangan, diantaranya adalah biaya dan resiko mahal, belum tersedianya infrastruktur yang luas, hingga pada tindak kejahatan perbankan yang dilakukan oleh pihak user sendiri. Namun demikian berbagai hambatan dan tantangan tersebut jangan dipandang sebagai ancaman, melainkan harus dimaknai sebagai tantangan untuk memicu berkreasi dengan inovasiinovasi guna memenangkan persaingan yang makin kompetitif.

\section{Daftar Pustaka}

A. Giordano, G. Spezzano, Smart agents and fog computing for smart city ap- plications, Smart Cities (2016) 137-146, doi:10.1007/978-3-31939595-1_14.

Azwar. 2017. Index of Syariah Financial Inclusion in Indonesia . Jurnal Bulein Ekonomi Moneter Perbankan (BEMP) Volume 20 Nomor 1 : Bank Indonesia

Bank Indonesia. (2014). Booklet Keuangan Inklusif. Jakarta. Departemen Pengembangan Akses Keuangan dan UMKM.

Creeber Glen, Martin Royston, (1914). Digital Culture Understanding New Media.

E. Nygren, R.K. Sitaraman, J. Sun, The Akamai network: a platform for high- performance internet applications, ACM SIGOPS Oper. Syst. 44 (3) (July 2010) 2-19.

Finanssialan keskusliitto 2015. Muuttuva työ finanssialalla. Cited 6.12.2016 \&

17.1.2017,

http://www.finanssiala.fi/materiaal it/Muuttuva_tyo_finanssialalla.pdf

Gartner 2016. Digitalization. Cited 28.11.2016,

http://www.gartner.com/itglossary/ digitalization/

K. Bilal, S.U.R. Malik, O. Khalid, A. Hameed, E. Alvarez, V. Wijaysekara, R. Ir- fan, S. Shrestha, D. Dwivedy, M. Ali, U.S. Khan, A. Abbas, N. Jalil, dan S.U. Khan, A taxonomy and survey on green data center networks, Future Gener. Comput. Syst. 36 (2014) 189-208.

K. Bilal, S.U.R. Malik, S.U. Khan, A.Y. Zomaya, Trends and challenges in cloud data centers, IEEE Cloud Comput. 1 (1) (2014) 10-20. 
K. Ha, P. Pillai, G. Lewis, S. Simanta, S. Clinch, N. Davies, M. Satyanarayanan, The impact of mobile multimedia applications on data center consolidation, in: 2013 IEEE International Conference on Cloud Engineering (IC2E), March 2013, pp. 166-176.

Koiranen, Ilkka, Räsänen, Pekka, Södergård, Caj 2010. Mitä digitalisaatio on tarkoittanut kansalaisen näkökulmasta?*. Talous ja yhteiskunta, 3, p. 24-29

Luhmann, N. (1962a). 'Funktion und Kausalität'. Kölner Zeitschrift für Soziologie und Sozialpsychologie, 19: 615-644.

Matt, C., Hess, T. \& Benlian, A. 2015, Digital Transformation Strategies, Business \& Information Systems Engineering, vol. 57, no. 5, pp. 339-343.

McKinsey \& Company melalui artikel "Structure is Not Organization" yang dimuat di Business Horizons pada Juni 1980 (Dalam Lauri Piirainen: 'Digitalization of the financial sector and change management - Case company: Bank X's digitalization and change management, Oulu University of Applied Sciences, (2017) DIB3SN.

Kashif Bilal, Osman Khalid, Aiman Erbad, Samee U. Khan. Potentials, trends, and prospects in edge technologiees: Fog, Cloudlet, mobile, edge, and micro data centers; Journal Computer Networks 130 ELSEVIER. (2017) 94-120.

Mohammad Nejatullah Siddiqi: Islamic Banking and Finance in Theory and Practice: A Survey of State of the Art, Islamic Economic Studies.
Vol 13, No. 2, February 2006.

O. Fratu, C. Pena, R. Craciunescu, Fog computing system for monitoring mild dementia and COPD patients, in: 12th International Conference on Telecom- munication in Modern Satellite, Cable and Broadcasting Services (TELSIKS), 2015, pp. 123-128.

Rangarajan Committee. (2008). Report of the Committee on Financial Inclusion. Government of India.

Sarma, M. (2012). Index of Financial Inclusion - A measure of financial sector inclusiveness. Berlin Working Papers on Money, Finance, Trade and Development, No.7, p.1-34.

Schinkel, T. 2000, The deepening of office digitization, Office Solutions, vol. 17, no. 10, pp. 3439.

Schumann, C. \& Tittmann, C. 2015, Digital Business Transformation in the Context of Knowledge Management, Academic Conferences International Limited, Kidmore End, 09, pp. 675.

W. Shi, J. Cao, Q. Zhang, Y. Li, L. Xu, Edge computing: vision and challenges, IEEE Internet Things J. 3 (5) (2016) 637-646.

World Bank. (2014). Financial Inclusion Data/Global Findex. http://datatopics.worldbank.org/fin ancialinclusion/country/indonesia

https://ekonomi.kompas.com/read/2017/ 04/18/210000426/bisnis.model.baru.ban k-.fintech.dan.ekonomi.digital.

https://ekonomi.kompas.com/read/2017/ 04/18/210000426/bisnis.model.baru.ban k-.fintech.dan.ekonomi.digital 